\title{
PENERAPAN METODE RELIABILITY CENTERED MAINTENANCE (RCM) BERBASIS WEB PADA SISTEM PENDINGIN PRIMER DI REAKTOR SERBA GUNA GA. SIWABESSY
}

\author{
MOHAMMAD TAHRIL AZIS ${ }^{1}$, M. SALMAN SUPRAWHARDANA ${ }^{1}$, \\ TEGUH PUDJI PURWANTO ${ }^{2}$ \\ ${ }^{1}$ Badan Pengawas Tenaga Nuklir (BAPETEN), \\ Jl. Gajah Mada 8, Jakarta Pusat, 10120 \\ ${ }^{2}$ Jurusan Teknik Mesin dan Industri, Fakultas Teknik UGM, \\ Jl. Grafika No.2 Kampus UGM Yogyakarta 55281
}

\begin{abstract}
Abstrak
PEMILIHAN METODE RCM (RELIABILITY CENTERED MAINTENANCE) PADA SISTEM PENDINGIN PRIMER PADA RSG GA. SIWABESSY.Terkait fungsinya sebagai pendingin utama reaktor RSG GA. Siwabessy, untuk menjamin suhu di dalam teras dan reflektor sesuai batas operasi yang diijinkan selama reaktor beroperasi. Komponen-komponen sistem pendingin primer yang terkait harus mengacu pada daya termal reaktor dan dapat meminimalkan kebolehjadian kegagalan (failure) pada komponen supaya dalam pengoperasiannya reaktor aman dan selamat. Pengembangan RCM (Relibility Centered Maintenance) berbasis web dengan perangkat lunak Free Open Source Software (FOSS) / GPL (General Public License), akan membantu sebagai sistem informasi pendukung perawatan yang bisa bekerja dalam jaringan intranet/internet. Free Open Source Software (FOSS) merupakan perangkat lunak yang dapat memberikan jaminan kepada penggunanya untuk melakukan pengembangan, sharing dan melakukan perubahan jika diperlukan, terutama pengguna merasa yakin bahwa software tersebut benar-benar legal dan bebas (free software). Metode RCM merekomendasikan sebanyak 52 jenis perawatan dari task selection untuk diterapkan pada sistem pendingin primer dengan rincian $35 \%$ time directed (18 task), $63 \%$ condition directed (33 task) dan $1 \%$ failure finding (1 task).
\end{abstract}

Kata kunci: Reliability Centered Maintenance, Free Open Source Software, Sistem Pendingin Primer, Web based System

\begin{abstract}
THE SELECTION METHOD OF RCM IN THE PRIMARY COOLING SYSTEM OF RSG GA. SIWABESSY RELATED TO FUNCTIONS AS THE PRIMARY COOLING REACTOR RSG GA. SIWABESSY. Reactor RSG GA. Siwabessy to ensure the temperature inside the reactor core and reflectors within the limits of allowable operations during reactor operation. The primary cooling system components must refer to the thermal power reactors and to minimize failure probability of components to operate the reactor in safe and secure. The RCM
\end{abstract}


Method Development (Reliability Centered Maintenance) with a web-based Free Open Source Software (FOSS)/GPL (General Public License), will assist the maintenance support information system that can work in the intranet / internet. Free Open Source Software (FOSS) is software that can provide assurance to the user to perform the development, sharing and make changes if necessary, especially users feel confident that the software actually legal and free (free software). The RCM method recommends maintenance types of 52 task selection to be applied in the primary cooling system with details time directed (td) 35\% (18 tasks), condition directed (cd) $63 \%$ (33 tasks) and 1\% failure finding (1 task).

Keywords: Reliability Centered Maintenance, Free Open Source Software, Primary Cooling system, Web based System.

\section{PENDAHULUAN}

Reaktor Serba Guna GA. Siwabessy (RSG-GAS) merupakan reaktor penelitian yang digunakan untuk penelitian, melayani kegiatan iradiasi, pendidikan dan pelatihan Fasilitas RSG-GAS dimiliki oleh Badan Tenaga Nuklir Nasional (BATAN). Keselamatan pengoperasian reaktor sangat erat kaitannya dengan konsep keandalan (reliability). Konsep tersebut membahas keandalan sistem yang digunakan untuk mengoperasikan reaktor dan keandalan sistem yang digunakan untuk mengantisipasi munculnya kebolehjadian kecelakaan awal. Keandalan pengoperasian reaktor dibangun dari keandalan masing-masing sistem dan keandalan masing-masing komponen penyusun sistem.

Program perawatan peralatan instalasi sistem pendingin primer di Reaktor Serba Guna G.A. Siwabessy (RSG-GAS) terbagi dalam dua bagian yaitu perawatan pencegahan (Preventive Maintenance) dan perawatan perbaikan (Corrective Maintenance). Perawatan pencegahan terdiri dari kegiatan service, uji operasi dan inspeksi secara rutin yang terjadwal. Sedangkan perawatan perbaikan disebabkan karena gangguan/kerusakan pada sistem atau komponen yang tidak terjadwal.

Penerapan metode RCM (Reliability Centered Maintenance) ${ }^{[1]}$ sudah lama dipakai di industri khususnya industri penerbangan komersial yang sekarang berkembang di berbagai sektor industri. Pada umumnya perangkat lunak (software) komputer untuk RCM merupakan perangkat lunak berlisensi yang tidak gratis dan hanya bisa bekerja atau diinstal untuk satu komputer (stand alone) saja. Pengembangan RCM berbasis web merupakan sistem informasi pendukung perawatan yang bisa bekerja dalam jaringan intranet/internet dengan perangkat lunak Free Open Source Software (FOSS) / GPL (General Public License), yaitu perangkat lunak yang memberikan jaminan kepada pengguna untuk melakukan duplikasi (sharing) serta melakukan perubahan jika diperlukan pada perangkat lunak yang 
didapatkannya, terutama untuk meyakinkan kepada pengguna tersebut bahwa software tersebut benar-benar bebas (free software).

Penerapan metode RCM akan memberikan keuntungan yaitu : keselamatan dan integritas lingkungan menjadi lebih lebih diutamakan, prestasi operasional yang meningkat, efektifitas biaya operasi dan perawatan yang lebih rendah, meningkatkan ketersediaan dan reliabilitas peralatan, umur komponen yang lebih lama, basis data yang lebih komprehensif, motivasi individu yang lebih besar, dan kerja sama yang baik diantara bagian-bagian dalam suatu instalasi.

Batasan masalah pengerjaan dan pembahasan ini sebagai berikut : (1) penelitian ini dilaksanakan pada sistem pendingin primer di Reaktor Serba Guna G.A. Siwabessy (RSG-GAS), (2) analisa RCM dilakukan hanya pada komponen utama sistem pendingin primer yaitu pompa, alat penukar panas dan katup dengan menggunakan metode tujuh langkah proses RCM, (3) data kegagalan dan kerusakan yang digunakan adalah data pada periode tanggal 1 Januari 2007 sampai dengan 30 Oktober 2008, dan (4) penelitian ini tidak dilakukan perhitungan biaya hasil pemeliharaan sistem pendingin primer.

Tujuan penelitian ini adalah : (1) mengetahui penerapan metode RCM untuk sistem pendingin primer yaitu dengan mendefinisikan fungsi dan kegagalan fungsi setiap aset-aset dalam sistem pendingin primer, serta mengidentifikasikan failure mode, failure cause, dan failure effect dari kegagalan fungsi sistem pendingin primer; (2) pembuatan program komputer metode RCM berbasis web sebagai sistem informasi pendukung perawatan yang bisa bekerja dalam jaringan intranet/internet dengan perangkat lunak Free Open Source Software (FOSS) / GPL (General Public License).

Hasil penelitian ini diharapkan bisa menambah wawasan manajemen perawatan sistem pendingin primer dengan metode RCM (Reliabiltiy Centered Maintenance), untuk dapat digunakan sebagai bahan pertimbangan dalam menerapkan kebijakan manajemen perawatan yang lebih baik.

\section{TEORI}

Reliability Centered Maintenance (RCM) mempunyai beberapa definisi adalah sebagai berikut :

1. Reliability Centered Maintenance ${ }^{[1]}$ adalah suatu proses yang digunakan untuk menentukan apa yang harus dikerjakan untuk menjamin setiap aset fisik tetap bekerja sesuai yang diinginkan atau suatu proses untuk menetukan perawatan yang efektif.

2. Reliability Centered Maintenance ${ }^{[2]}$ adalah suatu pendekatan pemeliharaan yang mengkombinasikan praktek dan strategi dari preventive maintenance $(\mathrm{pm})$ dan corective maintenance $(\mathrm{cm})$ untuk 
memaksimalkan umur (life time) dan fungsi aset / sistem / equipment dengan biaya minimal (minimum cost).

Prinsip - Prinsip RCM adalah ${ }^{[3]}$ : (1) memelihara fungsional sistem, bukan sekedar memelihara suatu sitem/alat agar beroperasi tetapi memelihara agar fungsi sistem / alat tersebut sesuai dengan harapan, (2) lebih fokus kepada fungsi sistem daripada suatu komponen tunggal, yaitu apakah sistem masih dapat menjalankan fungsi utama jika suatu komponen mengalami kegagalan; (3) berbasiskan pada kehandalan yaitu kemampuan suatu sistem/equipment untuk terus beroperasi sesuai dengan fungsi yang diinginkan; (4) bertujuan menjaga agar kehandalan fungsi sistem tetap sesuai dengan kemampuan yang didesain untuk sistem tersebut; (5) mengutamakan keselamatan (safety) baru kemudian untuk masalah ekonomi; (6) RCM mendefinisikan kegagalan (failure) sebagai kondisi yang tidak memuaskan (unsatisfactory) atau tidak memenuhi harapan, sebagai ukurannya adalah berjalannya fungsi sesuai performance standard yang ditetapkan; (7) RCM harus memberikan hasilhasil yang nyata / jelas, Tugas yang dikerjakan harus dapat menurunkan jumlah kegagalan (failure) atau paling tidak menurunkan tingkat kerusakan akaibat kegagalan.

\section{Metode RCM}

Pemilihan Sistem dan Pengumpulan Informasi ${ }^{[4]}$

Pemilihan sistem dapat didasarkan pada beberapa aspek kriteria yaitu :

1. Sistem yang mendapat perhatian yang tinggi karena berkaitan dengan masalah keselamatan (safety) dan lingkungan

2. Sistem yang memiliki preventive maintenance dan/atau biaya preventive maintenance yang tinggi.

3. Sisem yang memiliki tindakan corrective maintenance dan/atau biaya corrective maintenance yang banyak.

4. Sistem yang memiliki kontribusi yang besar atas terjadinya full atau partial outage (atau shutdown)

Dokumen atau informasi yang dibutuhkan dalam analisis RCM antara lain :

1. Piping \& Instrumentation Diagram (P\&ID) merupakan ilustrasi skematik dari hubungan fungsi antara perpipaan, instrumentasi, komponen peralatan dan sistem

2. Schematic / Block Diagram merupakan sebuah gambaran dari sistem, rangkaian atau program yang masing-masing fungsinya diwakili oleh gambar kotak berlabel dan hubungan diantaranya digambarkan dengan garis penghubung.

3. Vendor Manual yaitu berupa dokumen data dan informasi mengenai desain dan operasi tiap peralatan (equipment) dan komponen. 
4. Equipment History yaitu kumpulan data kegagalan (failure) komponen dan peralatan dengan data corrective maintenance yang pernah dilakukan.

\section{Definisi Batas Sistem ${ }^{[4]}$}

Definisi batas sistem (system boundary definition) digunakan untuk mendefinisikan batasan - batasan suatu sistem yang akan dianalisis dengan Reliability Centered Maintenance (RCM), berisi tentang apa yang harus dimasukkan dan yang tidak dimasukkan ke dalam sistem sehingga semua fungsi dapat diketahui dengan jelas dan perumusan system boundary definition yang baik dan benar akan menjamin keakuratan proses analisis sistem.

\section{Deskripsi Sistem dan Diagram Blok Fungsional ${ }^{[5]}$}

Deskripsi sistem dan diagram blok merupakan representasi dari fungsi-fungsi utama sistem yang berupa blok - blok yang berisi fungsi - fungsi dari setiap subsistem yang menyusun sistem tersebut, maka dibuat tahapan identifikasi detail dari sistem yang meliputi :

1. Deskripsi sistem

2. Functional Block Diagram

3. IN / OUT Interface

4. System Work Breakdown System

\section{Fungsi dan Kegagalan Fungsional ${ }^{[6]}$}

Fungsi (Function) adalah kinerja (performance) yang diharapkan oleh suatu sistem untuk dapat beroperasi, misalnya Gambar 1 tentang fungsi pompa. Functional Failure $(F F)$ didefinisikan sebagai ketidakmampuan suatu komponen /sistem untuk memenuhi standar prestasi (performance standard) yang diharapkan. Hal ini ditunjukkan pada Gambar 2.

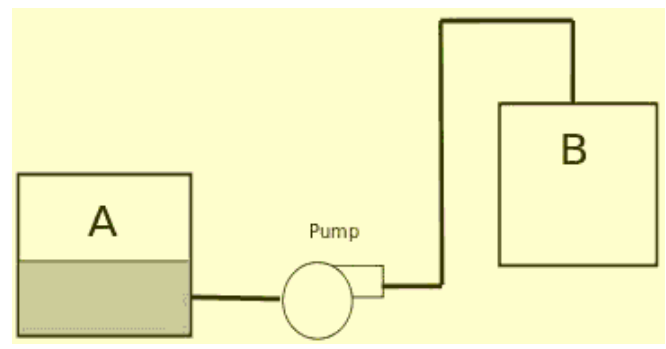

Gambar 1. Fungsi Pompa : Memompakan Fluida dari Tangki A ke Tangki B dengan Kapasitas $300 \mathrm{~m}^{3} / \mathrm{Jam}$ 


\begin{tabular}{|c|c|c|c|c|c|c|c|}
\hline \multicolumn{8}{|c|}{$\mathrm{RCM}$} \\
\hline \multicolumn{2}{|c|}{ Step 4} & $: S_{\mathbf{X}}$ & \multicolumn{5}{|c|}{ System Function and Functional Failure } \\
\hline \multicolumn{2}{|l|}{ Info } & \multicolumn{6}{|c|}{ Function and Functional Failure } \\
\hline \multicolumn{2}{|c|}{ Plant } & $\mathrm{R}$ & \multicolumn{3}{|c|}{ Reaktor RSG GA Siwabessy } & Analyst & M. Tahril Azis \\
\hline \multicolumn{2}{|c|}{ System } & \multicolumn{4}{|c|}{ Sistem Pendingin Primer } & Date & \\
\hline \multicolumn{2}{|c|}{ Komp. } & \multicolumn{4}{|c|}{ Pompa JE 01 AP 01} & & \\
\hline \multirow[t]{2}{*}{ No } & \multirow[t]{2}{*}{ Kode } & \multirow{2}{*}{\multicolumn{2}{|c|}{$\begin{array}{l}\text { Nama } \\
\text { Item }\end{array}$}} & \multicolumn{2}{|c|}{ Functions (F) } & \multicolumn{2}{|c|}{ Failure Function $(F F)$} \\
\hline & & & & Kode & Fungsi & Kode & Kegagalan Fungsi \\
\hline 1 & \multirow[t]{4}{*}{ A1 } & & & \multirow[t]{4}{*}{1.1} & & & \\
\hline 1 & & & & & & & \\
\hline 1 & & & & & & & \\
\hline 1 & & & & & & & \\
\hline 2 & \multirow[t]{3}{*}{ A2 } & & & 2.1 & & & \\
\hline 2 & & & & 2.1 & & & \\
\hline 2 & & & & 2.1 & & & \\
\hline
\end{tabular}

Gambar 2. Form Fungsi Sistem dan Fungsi Kegagalan ${ }^{[6][7]}$

Failure Mode and Effect Analysis (FMEA) ${ }^{[6]}$

Failure Mode and Effect Analysis (FMEA) adalah proses mengidentifikasi kegagalan dari suatu komponen yang dapat menyebabkan kegagalan fungsi dari sistem. Bentuk FMEA ditunjukkan pada Gambar 3. Failure Mode and Effect Analysis (FMEA) meliputi pengidentifikasian yaitu :

1. Failure Cause : penyebab terjadinya failure mode

2. Failure Effect : dampak yang ditimbulkan failure mode, failure effect ini dapat ditinjau dari 3 sisi level yaitu :

a. Komponen / Lokal

b. Sistem

c. Plant

\section{Logic Tree Analysis (LTA) ${ }^{[6]}$}

Penyusunan Logic Tree Analysis (LTA) merupakan proses yang kualitatif yang digunakan untuk mengetahu konsekuensi yang ditimbulkan oleh masing - masing failure mode.

Tujuan Logic Tree Analysis (LTA) adalah mengklasifikasikan failure mode ke dalam beberapa kategori sehingga nantinya dapat ditentukan tingkat prioritas dalam penangan masing-masing failure mode berdasarkan kategorinya . Format LTA pada pompa ditunjukkan pada Tabel 1. 
Tabel 1. Logic Tree Analysis pada pompa ${ }^{[8]}$

\begin{tabular}{llcccccc}
\hline \multirow{2}{*}{ No } & Functional Failure & No & Failure Mode & \multicolumn{3}{c}{ Criticality Analysis } & Com \\
\cline { 5 - 7 } & & & Evident & Safety & Outage & Category & \\
\hline 1. & Air tidak mengalir & 1 & Bearing rusak & $\mathrm{Y}$ & $\mathrm{N}$ & $\mathrm{Y}$ & $\mathrm{B}$ \\
1.1 & 2 & Motor terbakar & $\mathrm{Y}$ & $\mathrm{N}$ & $\mathrm{Y}$ & $\mathrm{B}$ \\
& & & Impeller rusaka & $\mathrm{Y}$ & $\mathrm{N}$ & $\mathrm{Y}$ & $\mathrm{B}$ \\
\hline
\end{tabular}

Tiga pertanyaan tersebut adalah sebagai berikut :

1. Evident yaitu : Apakah operator mengetahui dalam kondisi normal, telah terjadi gangguan dalam sistem ?

2. Safety yaitu : Apakah mode kerusakan ini menyebabkan masalah keselamatan?

Outage yaitu : Apakah mode kerusakan ini mengakibatkan seluruh atau sebagian mesin berhenti?

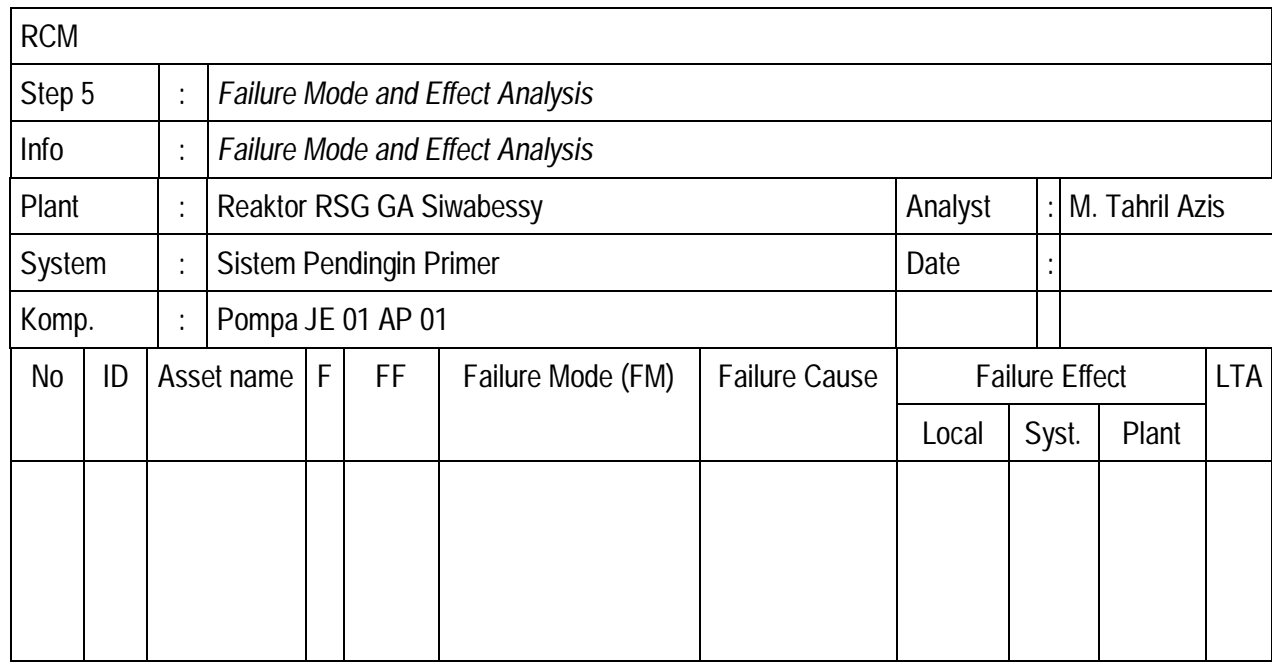

Gambar 3. Form Failure Mode and Effect Analysis (FMEA) ${ }^{[6]}$

Berdasarkan LTA tersebut failure mode dapat digolongkan dalam empat kategori yaitu :

1. Kategori A, jika failure mode mempunyai konsekuensi safety terhadap personel maupun lingkungan.

2. Kategori B, jika failure mode mempunyai konsekuensi terhadap operasional plant (mempengaruhi kuantitas ataupun kualitas output) yang dapat menyebabkan kerugian ekonomi secara signifikan.

3. Kategori $\mathbf{C}$, jika failure mode tidak berdampak pada safety maupun operasional plant dan hanya menyebabkan kerugian ekonomi yang relatif kecil untuk perbaikan. 
4. Kategori D, jika failure mode tergolong sebagai hidden failure, yang kemudian digolongkan lagi ke dalam kategori D/A, kategori D/B, dan kategori D/C.

\section{Pemilihan Tindakan (Task Selection)}

Pemilihan tindakan merupakan tahap terakhir dari proses analisa RCM. Dari tiap mode kerusakan dibuat daftar tindakan yang mungkin untuk dilakukan dan selanjutnya memilih tindakan yang paling efektif. Gambar 4 merupakan diagram alir pemilihan tindakan.

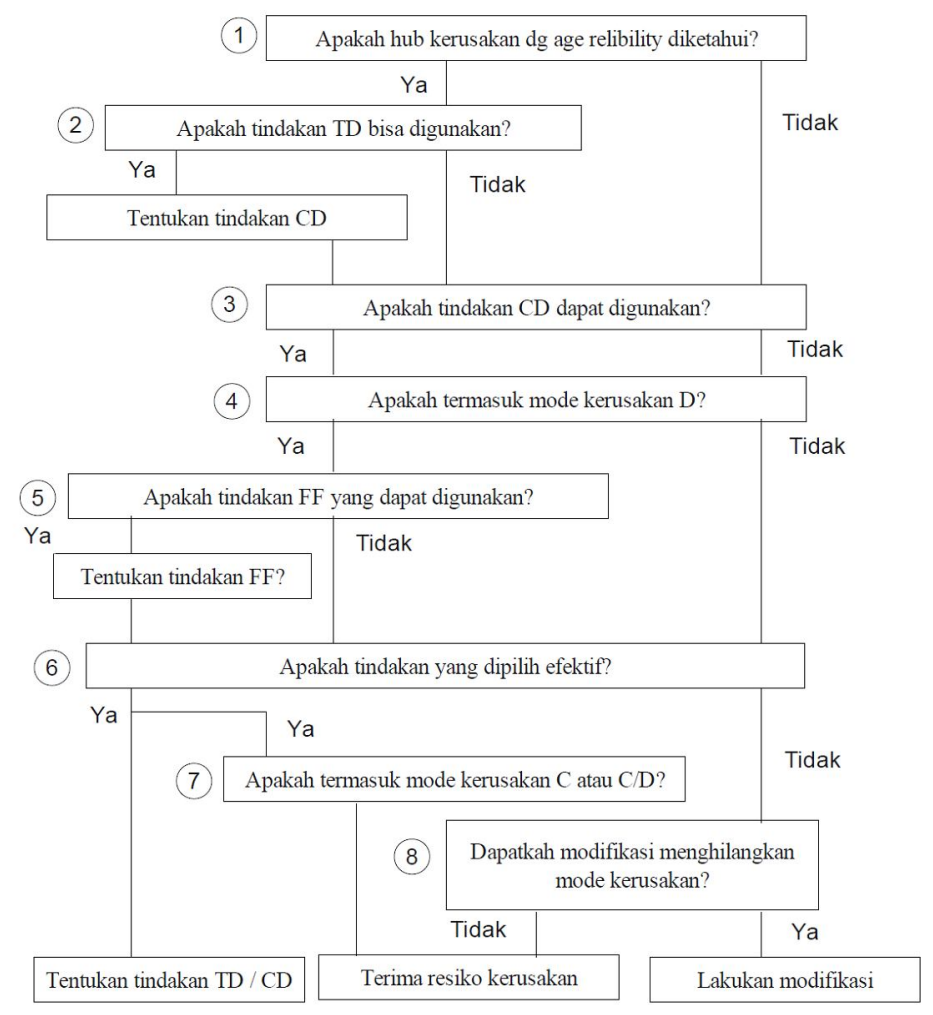

Gambar 4. Diagram Alir Pemilihan Tindakan

Dalam pelaksanaannya pemilihan tindakan dapat dilakukan dengan empat cara yaitu:

\section{Time Directed (TD)}

Suatu tindakan yang bertujuan melakukan pencegahan langsung terhadap sumber kerusakan peralatan yang didasarkan pada waktu atau umur komponen.

2. Condition Directed (CD)

Suatu tindakan yang bertujuan untuk mendeteksi kerusakan dengan cara memeriksa alat. Apabila dalam pemeriksaaan ditemukan gejala-gejala 
kerusakan peralatan maka dilanjutkan dengan perbaikan atau penggantian komponen.

3. Failure Finding (FF)

Suatu tindakan yang bertujuan untuk menemukan kerusakan peralatan yang tersembunyi dengan pemeriksaan berkala.

4. Run to Failure (RTF)

Suatu tindakan yang menggunakan peralatan sampai rusak, karena tidak ada tindakan yang ekonomis dapat dilakukan untuk pencegahan kerusakan.

\section{METODOLOGI}

Metodologi Penerapan Reliability Centered Maintenance (RCM) berbasis Web pada Sistem Pendingin Primer Reaktor Serba Guna GA. Siwabessy ini dilakukan secara bertahap, yang tersusun dalam langkah - langkah sebagai berikut:

\section{Objek Penelitian}

Sistem Pendingin Primer Reaktor Serba Guna GA Siwabessy (RSG-GAS), Badan Tenaga Nuklir Nasional (BATAN) di Serpong, Kabupaten Tangerang.

\section{Data yang digunakan}

Data yang digunakan dalam pembuatan tugas akhir ini adalah data yang berhubungan dengan objek penelitian yang diperlukan untuk proses analisa RCM yaitu :

1. Dokumen Permintaan Perbaikan dan Ijin Kerja (PPIK)

2. Dokumen Penuan Reaktor Serba Guna GA Siwabessy (RSG-GAS)

3. Laporan Analis Keselamatan (LAK)

4. Manual Operasi Reaktor Serba Guna GA Siwabessy (RSG-GAS)

5. Maintenance and Repair Manual : Primary Cooling System JE-01.

\section{Metode Pengumpulan Data}

1. Studi Literatur

Studi literatur berkaitan dengan studi dan pencarian literatur, prosiding seminar, journal dan Tugas Akhir yang berkaitan dengan metode Reliability Cenetered Maintenance (RCM), seperti perawatan dengan metode RCM dan Sistem Pendingin Primer di RSG-GAS.

2. Studi Lapangan

Melakukan kunjungan langsung ke Reaktor Serba Guna GA. Siwabessy Badan Tenagan Nuklir Nasional (BATAN) di Serpong - kabupaten Tangerang, untuk mempelajari dan mengambil data - data yang berkaitan dengan sistem pendingin primer.

3. Tanya Jawab 
Wawancara, diskusi atau tanya jawab secara langsung dengan petugas, teknisi lapangan dan pejabat di lingkungan Reaktor Serba Guna GA. Siwabessy, Badan Tenaga Nuklir Nasional (BATAN).

\section{Pembuatan Program Komputer}

\section{Instal Ubuntu 9.04 (Jaunty Jackalope)}

Pembuatan program komputer berbasis web pada tugas akhir ini menggunakan operating system (OS) Ubuntu 9.04 Jaunty Jackalope yaitu salah satu distribusi linux yang berbasiskan debian yang tersedia secara bebas dan mempunyai dukungan yang berasal dari komunitas linux maupun tenaga profesional, Ubuntu 9.04 disponsori oleh Canonical Ltd. Gambar 5 merupakan tahapan awal instalasi Ubuntu 9.04.

Apache Web server

Sebelum membuat program (scripting) komputer, terlebih dahulu harus diinstal apache web server melalui synaptic package manager yang terdapat pada menu di ubuntu atau bisa secara manual, seperti pada Gambar 6

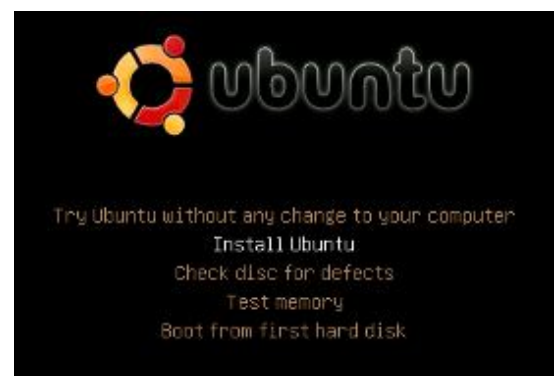

Gambar 5. Tahapan Awal Instalasi Ubuntu 9.04

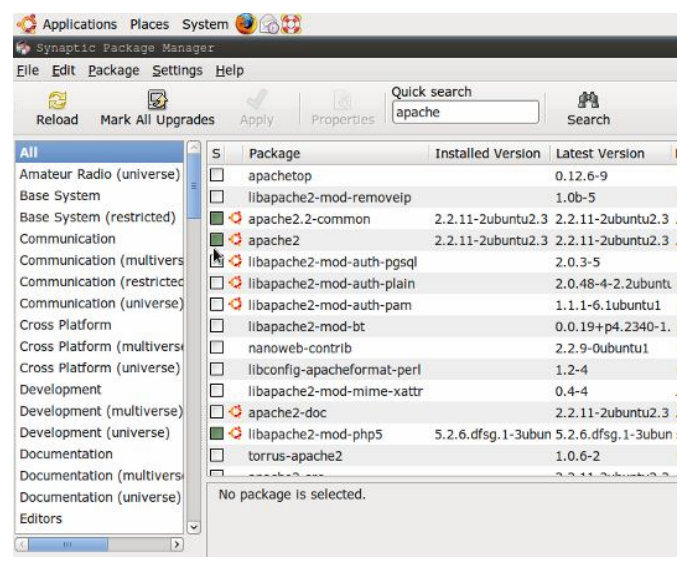

Gambar 6. Instal Apache Web Server melalui Synaptic Package Manager 
Apache berguna untuk melayani dan memfungsikan web. World Wide Web (www) merupakan aplikasi internet / intranet yang paling sukses dan merupakan komponen utama dari web server.

Pembuatan Program dengan Script PHP

Pembuatan program komputer menggunakan PHP 5 yaitu bahasa pemograman script yang dinamis dan dapat dijalankan sebagai aplikasi web yang memerlukan web server, PHP merupakan bahasa pemograman yang kaya dengan library untuk pengembangan aplikasi mulai dukungan ke data base management system dan dukungan library Graphical User Interfaces (GUI). Gambar 7 merupakan langkah penulisan script php.

MySQL dan Relational Database Management System (RDBMS)

MySQL merupakan Database Manajement System SQL open source yang paling populer yang dikembangkan dan didistribusikan dan didukung oleh MySQL AB yaitu sebuah perusahaan open source yang didirikan oleh para pengembang MySQL .

Untuk memudahkan pengelolaan database MySQL, perlu alat bantu adminitrasi data base berbasis web yang dibuat khusus yaitu phpMyAdmin atau phpMyAdmin merupakan front-end data base berbasisi web seperti yang ditunjukkan dalam Gambar 8

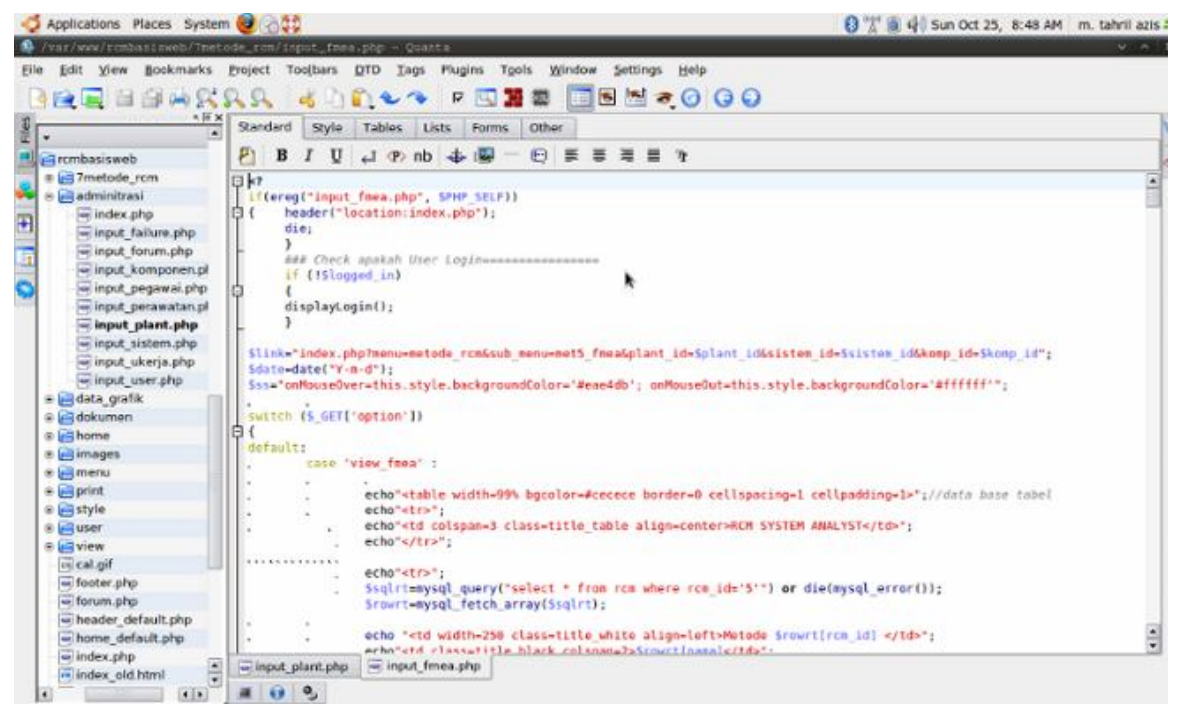

Gambar 7. Penulisan Script php dengan Quanta Editor 


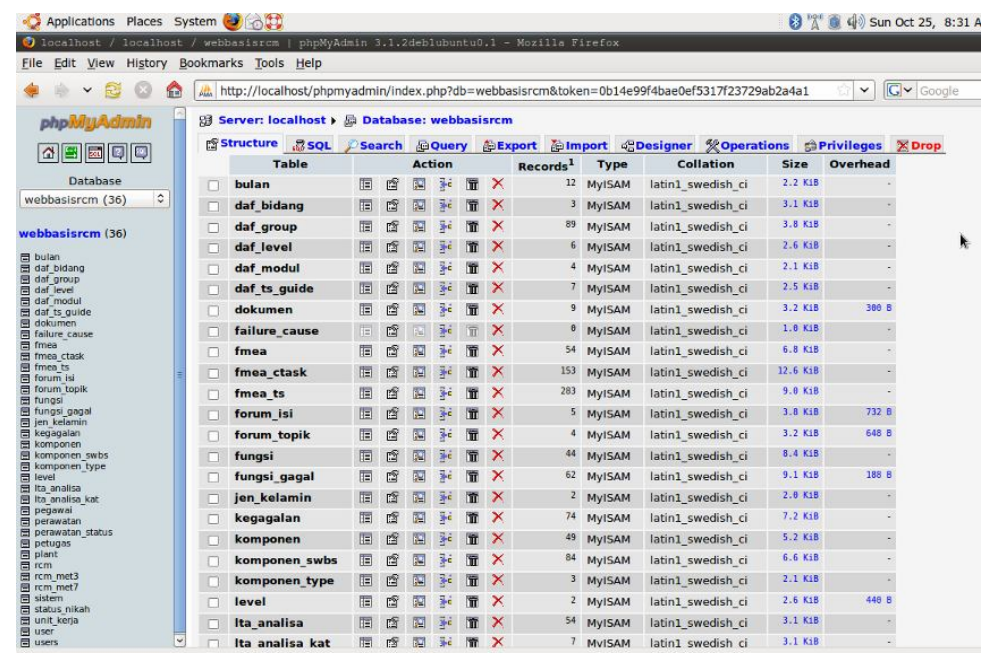

Gambar 8. Sistem Adminitrasi Web Data Base dengan phpmyadmin

Relational data base menggabungkan tabel-tabel dengan berbagai metode untuk dapat bekerja sama, hubungan - hubungan antar tabel data dapat dibandingkan, disatukan dan ditampilkan dalam form - form data base.

Perancangan Web (Web Design)

Perancangan halaman web (web page) dibuat sedemikian rupa, sehingga tampilannya dapat menarik dan mudah digunakan (user friendly), seperti pembuatan halaman login, menu, grafik dan lain-lain. Tampilan ini ditunukkan dalam Gambar 9.

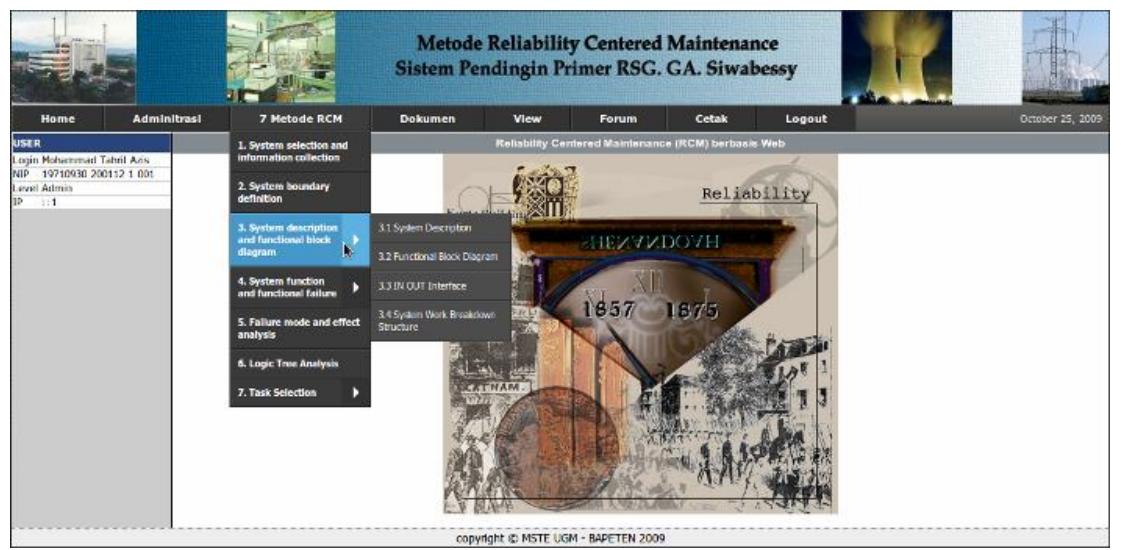

Gambar 9. Perancangan web, Halaman Utama dan Menu 


\section{HASIL DAN PEMBAHASAN}

\section{System Selection and Information Collection}

Pemilihan sistem pendingin primer pada RSG - GAS terkait fungsinya sebagai pendingin utama reaktor RSG - GAS, untuk menjamin suhu di dalam teras dan reflektor sesuai batas operasi yang diijinkan selama reaktor beroperasi.

Tabel 2. Data Komponen Sistem Pendingin Primer di RSG GA. Siwabessy

\begin{tabular}{|c|c|c|}
\hline No & Nama Komponen & Kode \\
\hline 1 & Pompa & JE 01 AP 01 \\
\hline 2 & Pompa & JE 01 AP 02 \\
\hline 3 & Pompa & JE 01 AP 03 \\
\hline 4 & Katup & JE 01 AA 01 \\
\hline 5 & Katup & JE 01 AA 02 \\
\hline 6 & Katup & JE 01 AA 03 \\
\hline 7 & Katup & JE 01 AA 04 \\
\hline 8 & Katup & JE 01 AA 05 \\
\hline 9 & Katup & JE 01 AA 06 \\
\hline 10 & Katup & JE 01 AA 07 \\
\hline 11 & Katup & JE 01 AA 08 \\
\hline 12 & Katup & JE 01 AA 09 \\
\hline 13 & Katup & JE 01 AA 10 \\
\hline 14 & Katup & JE 01 AA 11 \\
\hline 15 & Katup & JE 01 AA 12 \\
\hline 16 & Katup & JE 01 AA 13 \\
\hline 17 & Katup & JE 01 AA 14 \\
\hline 18 & Katup & JE 01 AA 15 \\
\hline 19 & Katup & JE 01 AA 16 \\
\hline 20 & Katup & JE 01 AA 17 \\
\hline 21 & Katup & JE 01 AA 18 \\
\hline 22 & Katup & JE 01 AA 19 \\
\hline 23 & Penukar Panas & JE 01 BC 001 \\
\hline 24 & Penukar Panas & JE 01 BC 002 \\
\hline
\end{tabular}


Komponen - komponen sistem pendingin primer yang terkait harus mengacu pada daya termal reaktor dan dapat meminimalkan kebolehjadian kegagalan (failure) pada komponen supaya dalam pengoperasiannya reaktor aman dan selamat. Komponen - komponen dalam sistem pendingin primer yaitu pada Tabel 2.

Sedangkan pengumpulan data - data kegagalan (failure mode) dan kerusakan yang digunakan adalah data pada periode tanggal $01-01-2007$ sampai dengan $30-10-2008$

\section{System Boundary Definition}

Sistem pendingin reaktor terdiri dari sistem pendingin primer, sistem pendingin sekunder dan sistem pendingin kolam, pada pembahasan ini hanya dipilih sistem pendingin primer, seperti pada Gambar 10.

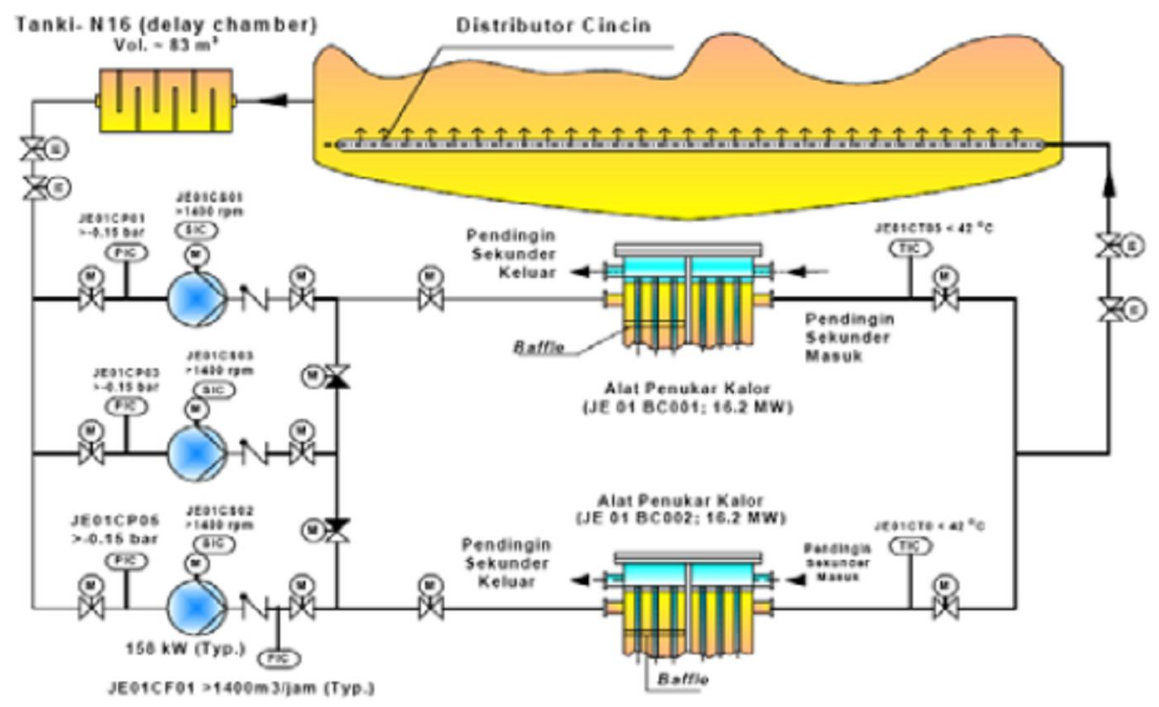

Gambar 10. Sistem Pendingin Primer

\section{System Description}

Sistem pendingin primer berfungsi mengambil panas dari teras dan reflektor, Air pendingin primer diisap melalui teras dan reflektor kemudian keluar melalui pipa outlet utama. Pendingin mengalir melalui pipa tersebut ke dalam delay chamber yang berada di sebelah kolam reaktor, untuk memperlambat jalannya aliran sehingga peluruhan $\mathrm{N}-16$ (waktu paroh 7,2 detik) diluruhkan dalam waktu yang cukup kira - kira 50 detik.

Tiga pompa primer mempunyai jenis dan kemampuan sama, pada operasi normal dua pompa beroperasi secara paralel dan pompa ketiga sebagai cadangan (tidak beroperasi bila reaktor sedang dioperasikan). 
Air pendingin primer mengalir melewati saluran sel penukar panas, sebelum kembali ke kolam reaktor, outlet kedua penukar panas digabung melewati satu pipa aliran balik, Pipa ini melewati ruang katup kemudian menembus dinding kolam reaktor dan berakhir pada distributor cincin yang berada di dasar kolam (level $+4 \mathrm{~m}$ ) dimana air primer yang telah dingin dipancarkan keluar. Setelah dipancarkan, air diisap ke dalam teras reaktor melalui bagian atas teras.

\section{System function and functional failure}

Selanjutnya metode RCM yang ke 4 adalah mendefinisikan fungsi dan kegagalan fungsi. Contoh pendefinisian fungsi dan kegagalan fungsi dari pompa pendingin primer dapat dilihat pada Tabel 3 Fungsi dan kegagalan fungsi.

Tabel 3. Fungsi dan Kegagalan Fungsi dari Pompa

\begin{tabular}{lll}
\hline No & \multicolumn{1}{c}{ Fungsi } & \multicolumn{1}{c}{ Kegagalan fungsi } \\
\hline $1 \quad \begin{array}{l}\text { Mengalirkan air pendingin dari teras } \\
\text { reaktor menuju satuan penukar panas } \\
\text { (HE) dan Menghasilkan aliran yang } \\
\text { mencukupi dalam pengambilan panas } \\
\text { yang dibangkitkan dari permukaan pelat } \\
\text { bahan bakar nuklir. }\end{array}$ & $\begin{array}{r}\text { 1.1 } \\
\text { Air pendingin yang mengalir dari teras } \\
\text { menuju ke HE tidak mencukupi dan Air } \\
\text { pendingin yang mengalir melalui teras } \\
\text { berkurang }\end{array}$ \\
& $1.2 \begin{array}{l}\text { Aliran pendingin sirkulasi primer akan } \\
\text { lebih kecil dari 2150 m3/Jam, Panas yang } \\
\text { harus dibuang dari elemen bakar nuklir } \\
\text { menjadi berkurang, sehingga dapat }\end{array}$ \\
& meningkatkan akumulasi panas pada \\
& bundel bahan bakar \\
$2 \quad \begin{array}{l}\text { Menghasilkan tekanan air pendingin } \\
\text { dalam loop primer merata di sepanjang } \\
\text { pipa, dan mendorongnya ke dalam } \\
\text { penukar panas (HE). }\end{array}$ & $2.1 \begin{array}{l}\text { Tekanan air pendingin didalam pipa } \\
\text { primer meningkat apabila terjadi } \\
\text { penurunan aliran air menjadi }>0,25 \text { Bar }\end{array}$ \\
\hline
\end{tabular}

\section{Failure Mode and Effect Analysis (FMEA)}

FMEA mengidentifikasi 54 failure mode yang berpotensi menyebabkan terjadinya functional failure pada komponen sistem pendingin primer. Dari failure mode tersebut diidentifikasi failure cause karena kegagalan indikasi pada mechanical $59 \%$, electrical $31 \%$ dan instrumentation 10\%. Analisa dilakukan pula pada failure effect terhadap local (komponen), system (pendingin primer) dan plant (RSG-GAS).

Selanjutnya dari 54 failure mode tersebut akan dianalis lebih lanjut dengan Logic Tree Analysis (LTA). Dasar yang digunakan dalam 
menentukan failure mode yang akan dimasukkan dalam LTA adalah efek yang ditimbulkan terhadap sistem.

\section{Logic Tree Analysis (LTA)}

Hasil Logic Tree Analysis yang ditunjukkan pada Tabel 4, dari total 54 failure mode menunjukkan bahwa $24 \%$ diantaranya adalah kategori A, $65 \%$ kategori A/B, 7\% kategori B, 4\% kategori C, sedangkan untuk kategori D/A, $\mathrm{D} / \mathrm{B}$ dan $\mathrm{D} / \mathrm{C}$ adalah $0 \%$ hal ini karena operator mengetahui dalam kondisi normal telah terjadi gangguan dalam sistem, sehingga jarang terjadi peristiwa hidden failure. Setiap terjadi gangguan pada sistem langsung ditangani oleh petugas perawatan dari hasil laporan operator pada hari itu juga.

Tabel 4. Hasil Logic Tree Analysis

\begin{tabular}{lll}
\hline Kategori & \multicolumn{2}{l}{ Failure Mode } \\
\hline & Jumlah & $\%$ \\
\hline $\mathrm{A}$ & 13 & $24.00 \%$ \\
$\mathrm{~B}$ & 4 & $7.00 \%$ \\
$\mathrm{C}$ & 2 & $4.00 \%$ \\
$\mathrm{~A} / \mathrm{B}$ & 35 & $65.00 \%$ \\
$\mathrm{D} / \mathrm{A}$ & 0 & $0.00 \%$ \\
$\mathrm{D} / \mathrm{B}$ & 0 & $0.00 \%$ \\
$\mathrm{D} / \mathrm{C}$ & 0 & $0.00 \%$ \\
\hline
\end{tabular}

\section{Task Selection}

Analisis task selection untuk mengidentifikasi candidate task terhadap 52 failure mode kecuali kategori pada LTA. Tabel 5 merupakan hasil task selection process menurut jenis perawatannya.

Tabel 5. Hasil Task Selection Proces

\begin{tabular}{lc}
\hline \multicolumn{1}{c}{ Decision Task } & Jumlah \\
\hline Time Directed $(T D)$ & 18 \\
Condition Directed $(C D)$ & 33 \\
Failure Finding $(F F)$ & 1 \\
Run to Failure $(R T F)$ & - \\
\hline
\end{tabular}




\section{KESIMPULAN}

Kesimpulan dari hasil analisa dan pembahasan adalah sebagai berikut :

1. Data kegagalan (failure mode) pada sistem pendingin primer di RSGGAS karena kegagalan indikasi pada mechanical $59 \%$, electrical $31 \%$ dan instrumentation $10 \%$.

2. Logic Tree Analysis dari total 54 failure mode menunjukkan bahwa $24 \%$ diantaranya adalah kategori $\mathrm{A}, 65 \%$ kategori $\mathrm{A} / \mathrm{B}, 7 \%$ kategori $\mathrm{B}, 4 \%$ kategori $\mathrm{C}$, sedangkan untuk kategori D/A, D/B dan D/C adalah $0 \%$.

3. Metode RCM merekomendasikan sebanyak 52 jenis perawatan dari Task selection untuk diterapkan pada sistem pendingin primer dengan rincian $35 \%$ time directed (18 task), 63\% condition directed (33 task) dan $1 \%$ failure finding (1 task).

\section{UCAPAN TERIMA KASIH}

Penulis mengucapkan terima kasih kepada Ir. Yusi Eko Yulianto, Dipl.Ing, Kepala Bidang Sistem Reaktor, RSG GA. Siwabessy - BATAN atas waktu, kesempatan dan dukungannya yang diberikan kepada penulis; Ir. Sugeng Sumbarjo.M.Eng, Kepala Biro Perencanaan - BAPETEN, pemerhati dan pelaku Bapeten Go Open Sources (BAGOES); Heru Eka Sanjaya, A.Md, atas bantuannya sebagai teman tempat bertanya dan memberikan solusi dalam penyelesaian scripting program; dan semua pihak terkait, penulis tidak dapat menyebutkan satu - persatu.

\section{DAFTAR PUSTAKA}

1. MOUBRAY, JOHN, 1992, Reliability Centered Maintenance, Second Edition, Industrial Press Inc.

2. HENLEY, E.J dan H. KUMAMOTO, 1981, Reliability Engineering and Risk Assesment, New Jersey : Prentice Hall.

3. RAUSAND, MARVIN, 1998, Reliability Centered Maintenance, Department of Production and Quality Engineering, Nurwegian University Science and Technology.

4. DEPHANDE, V.S. and JP MODAK, 2001, Application of RCM to Medium Scale Industry, Department of Mechanical Engineering, P.C.E. \& A, Nagpur University, Maharashanta, India.

5. IAEA-TEC DOC 658, 1992, "Safety related maintenance in the framework of the reliability centered maintenance concept", Vienna: IAEA.

6. IAEA-TECDOC 1590, 2007, "Aplication of Reliability Maintenance to Optimize Operation and Maintenance in Nuclear Power Plant", Vienna: IAEA. 
7. WILDAN, M. WAZIZ, 2009, "Handout Mata Kuliah Sistem Perawatan, Reliability Centered Maintenance (RCM)", Jurusan Teknik Mesin dan Industri, Fakultas Teknik UGM,

8. SUPRAWHARDANA, M. SALMAN, SUPRIYONO, 2001, "Uji Mutu Pompa Daya 160KW Menggunakan Analisis Reliabilitas", Laporan Teknis Berkala MIPA Vol. 9 No.1 Maret 2001. 